\title{
ANALISIS YURIDIS PENGATURAN ABORTUS PROVOKATUS TERHADAP KORBAN PEMERKOSAAN DI INDONESIA
}

\author{
Rina Shahriyani Shahrullah ${ }^{1}$, Elza Syarief $^{2}$, Lu Sudirman $^{3}$, dan Tedy Surya ${ }^{4}$ \\ Fakultas Hukum, Universitas Internasional Batam, Batam, Kepulauan Riau \\ Sei Ladi, Jl. Gajah Mada, Baloi Permai, Kec. Sekupang, Kota Batam, Kepulauan Riau \\ 29442 \\ 1rina@uib.ac.id, ${ }^{2}$ elza@uib.ac.id, ${ }^{3}$ dirman_lu@yahoo.com, ${ }^{4}$ tedysuryanatael@gmail.com
}

\begin{abstract}
Abortion or abortus provokatus constitutes a termination of pregnancy before the time of delivery. The objective of the study is to ascertain if the Abortion-related Health Law is a realistic rule based on the health aspects, as well as to analyze how long it should be allowed by the Health Law to perform an abortion according to medical criteria. The study uses a method of normative legal research. It concludes that the Health Law pertaining abortion is a realistic rule based on health aspects. Yet, it is necessary to revise the abortion rules due to rape incidents. The rules permits the abortion if the gestational age is 6 (six) weeks or 40 (forty) days. It is calculated from the first day of the last period. It suggests that the gestational age should be 12 (twelve) weeks or 3 (three) months from the first day of the last period.
\end{abstract}

Keymords: Abortus Provocatus, Legal Protection, Rape Victims

\begin{abstract}
Abstrak, Aborsi atau abortus provokatus merupakan penghentian hasil kehamilan sebelum tibanya waktu melahirkan. Penelitian ini bertujuan untuk mengetahui apakah Hukum Kesehatan yang terkait aborsi merupakan aturan yang realistis berdasarkan aspek kesehatan, serta menganalisis berapa jangka waktu yang seharusnya diperbolehkan oleh UU Kesehatan untuk melakukan aborsi sesuai kriteria medis. Penelitian ini menggunakan metode penelitian hukum normative. Penelitian ini menyimpulkan bahwa Undang-Undang Kesehatan terkait aborsi merupakan aturan yang realistis berdasarkan aspek kesehatan. Hanya saja perlu dilakukan revisi terhadap aturan aborsi terkait akibat perkosaan. Ketentuan memperbolehkan dilakukan aborsi jika usia kehamilan 6 (enam) minggu atau 40 (empat puluh) hari. Usia tersebut dihitung sejak hari pertama dari haid terakhir. Penelitian ini menyarankan agar ketentuan tersebut sebaiknya diubah menjadi 12 (dua belas) minggu atau 3 (tiga) bulan dihitung sejak hari pertama dari haid terakhir.
\end{abstract}

Kała Kunci: Abortus Provokatus, Perlindungan Hukum, Korban Perkosaan

\section{Pendahuluan}

Terdapat hak yang sangat mendasar dalam hal pelayanan kesehatan reproduksi pada kehidupan wanita, dan aborsi merupakan salah satunya. Pada hekekatnya aborsi tidak dapat direstui jika ditinjau dari sudut pandang Hak Asasi Manusia (HAM), tetapi jika nyawa dan kehidupan sang ibu dalam bahaya jika melanjutkan kehamilan dan sudah 
dikonfirmasi oleh tim ahli, tentu hal ini menjadi berbeda. ${ }^{1}$ Aborsi pun dapat dilakukan, karena sang ibu juga berhak untuk mempertahankan kehidupannya. Perdebatan tentang kejadian aborsi di Indonesia semakin ramai dibicarakan dewasa ini yang dipicu oleh semakin banyaknya angka kejadiannya. Pembahasan aborsi tentu tekait dengan kehidupan si ibu dan juga anak di dalam kandungannya. Selalu saja terjadi diskusi hangat dan adu pendapat yang membahas tentang aborsi dalam pertemuan formal dan informal yang berhubungan dengan dunia kedokteran, ilmu hukum ataupun disiplin ilmu yang lainnya. $^{2}$

Aborsi atau kita kenal dengan sebutan abortus provokatus berasal dari kata abortus dengan arti keguguran/ gugur kandungan. ${ }^{3}$ Abortus provokatus atau aborsi memiliki definisi yaitu berhentinya kehamilan atau keluarnya janin yang berada di rahim sebelum waktu untuk melahirkan dicapai. Dengan kata lain, pengeluaran janin tersebut disengaja, baik itu dengan obat-obatan, alat ataupun tindakan manusia. ${ }^{4}$

Tindakan menggugurkan kandungan atau aborsi pada hakekatnya tidak dapat dipisahkan serta sangat berkaitan erat dengan nilai dan norma-norma yang dianut oleh bangsa Indonesia dalam bermasyarakat dan bernegara. Ketentuan aborsi di atur dalam Kitab Undang-Undang Hukum Pidana (KUHP) khususnya pada Pasal 299, 346, 347, 348, 349 dan 350. Pasal-pasal tersebut merupakan ketentuan hukum pidana positif yang secara khusus mengatur aborsi. Perbuatan abortus criminalis sebagaimana dicantumkan pada Pasal 346, 347, dan 348 KUHP terdiri dari tindakan-tindakan membunuh kandungan (de dood van vrucht veroorzaken) dan menggugurkan kandungan (afdrijving van de vrucht). ${ }^{5}$

Pengaturan di dalam KUHP tentang abortus provocatus adalah warisan Belanda yang dirasa berseberangan terhadap landasan dan politik hukum yaitu Pancasila dan UUD 1945 dikarenakan abortus provokatus dilarang tanpa kecuali. Berkaca pada Pasal 349 KUHP, maka pidana penjara dapat mengancam tenaga medis dan paramedis yang bisa dituduh melakukan pelanggaran hukum. Padahal mungkin abortus provokatus yang dilakukan bertujuan untuk menyelamatkan nyawa sang ibu. Jika dilihat dari sudut pandang tersebut, tenaga medis dan paramedis jelas membutuhkan suatu payung hukum yang memberikan perlindungan hukum dalam melaksanakan tugas dan tanggung jawabnya. Disinilah kehadiran Undang-Undang Nomor 36 Tahun 2009 tentang Kesehatan (UU Kesehatan) dapat menjawab kebutuhan akan aturan baru tersebut.

Hadirnya UU Kesehatan, ikut mengatur aborsi, yang dimana Pasal 75 ayat (1) melarang dilakukannya aborsi tetapi terdapat pengecualian, yaitu juga terdapat indikasi

\footnotetext{
${ }^{1}$ Linda Fidawaty. "Aborsi dalam Perspektif Hak Asasi Manusia dan Hukum Islam (Analisis terhadap Peraturan Pemerintah No. 61 tahun 2014 tentang Kesehatan Reproduksi)", Al-'Adalah, 14(1), 107-130, 2017, hlm. 109.

${ }^{2}$ Achadiat Charisdiono, Dinamika Etika dan Hukum Kedokteran, Jakarta: Buku Kedokteran, 2007, hlm. 12.

${ }^{3}$ Rukmini Mien. Laporan Akhir Penelitian Tentang Aspek Hukum Pelaksanaan Aborsi Akibat Perkosaan, Jakarta: Badan Pembinaan Hukum Nasional Departemen Kehakiman dan HAM, 2002.

${ }^{4}$ Kusmaryanto. Kontroversi Aborsi, Jakarta : Gramedia Widiasarana Indonesia, 2002, hlm. 32.

${ }^{5}$ Musa Perdanakusuma. Bab Bab Tentang Kedokteran Forensik. Jakarta: Ghalia Indonesia, 1984, hlm. 192 .
} 
kedaruratan medis yang dideteksi sejak dini kehamilan, serta kehamilan akibat perkosaan. Akan tetapi Pasal 76 UU Kesehatan menetapkan batasan waktu yang diperbolehkan untuk melakukan aborsi yaitu maksimal umur kehamilan 6 (enam) minggu yang terhutung dari hari pertama dari haid terakhir seorang wanita. Namun hal ini dikecualikan jika teradapat keadaan medis yang darurat. ${ }^{6}$

Adanya ketentuan pembatasan yang sangat singkat ini tentu akan menimbulkan kasus dimana korban pemerkosaan belum sempat mendeteksi atau mengetahui bahwa dia hamil dan tentu saja belum sempat melakukan aborsi yang merupakan jalan keluar terbaik saat keadaan itu akan membuat gangguan psikologis yang mendalam didalam dirinya. Maka, penelitian ini bertujuan untuk mengetahui apakah UU Kesehatan yang terkait abortus provokatus merupakan aturan yang realistis berdasarkan aspek kesehatan, serta untuk mengkaji apakah jangka waktu yang ditetapkan oleh UU Kesehatan untuk melakukan abortus provokatus sudah sesuai dengan aspek kesehatan.

\section{Metode Penelitian}

Penelitian ini menggunakan metode penelitian hukum normatif (legal research) yang menekankan pada studi dokumen atau penelitian kepustakaan. Oleh karena itu penelitian ini lebih menitikberatkan pada penggunaan data sekunder. ${ }^{7}$ Data sekunder yang dimaksud adalah sumber data penelitian yang diperoleh melalui secara tidak langsung melalui suatu studi kepustakaan. Data tersebut berasal dari hasil penelitian dalam bentuk artikel jurnal, buku, maupun arsip tidak dipublikasikan ataupun yang telah secara umum dipublikasikan. ${ }^{8}$ Data sekunder dalam penelitian ini yang terdiri atas bahan hukum primer, bahan hukum sekunder dan bahan hukum tersier. Bahan hukum primer berupa UU Kesehatan. Bahan hukum sekunder antara lain hasil penelitian, buku-buku atau artikel jurnal yang terkait dengan kajian abortus provokatus. Bahan hukum tersier berupa artikel online sebagai data pendukung bahan-bahan hukum sesbelumnnya. Analalis data untuk penelitian ini menggunakan metode analisis deskriptif-kualitatif yang bertujuan untuk memberikan argumentasi dan kesimpulan yang tepat.

\section{Hasil Penelitian dan Pembahasan}

\section{Ketentuan Aborsi dalam UU Kesehatan Berdasarkan Aspek Kesehatan}

Aborsi dapat dikatakan sebagai matinya janin atau dikeluarkan dan berhentinya kehamilan saat panjang janin masih kurang dari $25 \mathrm{~cm}$ dan berat janin kurang dari 500

\footnotetext{
6 Mufidatul Ma'sumah. "Penjatuhan Pidana Terhadap Anak Korban Perkosaan Inses Yang Melakukan Aborsi”, Jurnal Yudisial, 12(2), 255-268, 2019, 262.

${ }^{7}$ Triana Dewi Seroja, Winda Fitri. "Implementasi dan Implikasi Asas Kekhususan Sistematis pada Tindak Pidana Telekomunikasi”, Journal of Law and Policy Transformation, 4(2), 104-122, 2019, hlm. 106.

${ }^{8}$ Sahuri Lasmadi, Ahmad Rofiq, Hari Sutra Disemadi, Sholahuddin Al-Fatih. "Islamic Criminal Law Review on the Duality of Principles of Legality in the Draft of Indonesia Criminal Law Code", International Journal of Innovation, Creativity and Change, 14 (2), 942-958, 2020, hlm. 943.
} 
gram atau terjadi sebelum usia kehamilan 20 minggu (dihitung sejak hari pertama haid terakhir). ${ }^{9}$ Sebenarnya kandungan perempuan bisa digugurkan tanpa memiliki batasan waktu secara pasti. Selama dijumpai indikasi medis untuk menggugurkan kandungan itu, maka kapan saja kandungan perempuan tersebut bisa digugurkan. Abortus provocatus masih boleh dilakukan atas dasar pertimbangan medis meskipun usia janin itu sudah mencapai lima bulan atau enam bulan. ${ }^{10}$ Abortus dapat dikategorikan atas dua jenis berdasarkan ilmu kesehatan dan kedokteran. Yang pertama adalah abortus spontaneous, dimana kandungan gugur tanpa campur tangan dan unsur kesengajaan manusia, atau secara alamiah. Kedua adalah abortus provocatus, dimana keguguran terjadi akibat campur tangan manusia dan terdapat unsur kesengajaan. ${ }^{11}$

Berkaca pada Pasal 75 ayat (2) UU Kesehatan, kandungan yang digugurkan berdasarkan adanya alasan kedaruratan medis disebut juga Abortus provocatus medicinalis/therapeuticus. Sedangkan abortus provokatus criminalis pada umumnya dikerjakan bertujuan untuk membuang janin yang berada dalam rahim atau mengakhiri kehamilan yang tidak dikehendaki akibat hubungan seksual di luar nikah. ${ }^{12}$

Faktor-faktor yang mempengaruhi perilaku aborsi pada perempuan adalah karena adanya faktor ekonomi, faktor banyak anak dan faktor sosial.

1. Faktor ekonomi yakni berkaitan dengan kemiskinan karena pelaku aborsi berasal dari status sosial ekonomi ke bawah.

2. Faktor banyak anak terkait dengan jumlah anak yang dimiliki

3. Faktor sosial terkait dengan takut kehamilan akan mengganggu pekerjaan, rasa malu dan rasa bersalah karena telah melakukan aborsi.

Apalagi saat remaja mengalami kehamilan yang tak diinginkan, baik karena pergaulan bebas ataupun akibat perkosaan, maka dia akan mengalami tekanan psikologis dari dirinya sendiri, orangtua, masyarakat, dan lingkungannya. Sementara yang telah diketahui bahwa ada regulasi yang melarang siswa menikah saat dia masih sekolah. Jika pun ini terjadi maka dia akan dikeluarkan dari sekolahnya dan dilarang melanjutkan studinya. Dengan demikian, aborsi menjadi banyak pilihan bagi remaja yang hamil di luar nikah.

Tindakan aborsi menurut Kitab Undang Undang Hukum Pidana di Indonesia dikatagorikan sebagai tindakan kriminal atau dikatagorikan sebagai kejahatan terhadap nyawa. Pasal Pasal KUHP yang mengatur hal ini adalah Pasal 229, 346-349, dan 535. Diterangkan bahwa Pasal 346 akan sama-sama menjerat seorang ibu yang mengandung maupun orang lain yang membantu untuk melakukan perbuatan melakukan aborsi secara sengaja, terhadap janin yang dikandungnya. KUHP Indonesia melarang abortus provokatus tanpa terkecuali, termasuk abortus provokatus medicalisdan abortus

\footnotetext{
9 Maria Ulfah Ansor, Wan Nedra, dan Sururin. Aborsi Dalam Perspektif Fiqh Kontemporer. Jakarta: Balai Penerbit Fakultas Kedokteran Universitas Indonesia, 2002, hlm. 158.

${ }^{10}$ Suryono Ekototama. Abortus Prookatusbagi Korban Perkosaan Perspektif Viktimologi, Kriminologi dan Hukum Pidana. Yogyakarta: UniversitasAdmajaya, 2001, hlm. 35.

${ }^{11}$ Musa Perdanakusuma. Op.Cit., hlm.191

${ }^{12}$ Abdul Aziz Dahlan. Ensiklopedi Hukum Islam. Jakarta: PT. Ikhtisar Baru Van Hoev, 1996, hlm. 7.
} 
provokatus therapeuticus. Tetapi justru diperbolehkan terjadinya aborsi provokatus medicalis dengan sepesifikasi therapeutics dalam UU Kesehatan.

Ketentuan Pasal 75 ayat (1) UU Kesehatan serupa dengan ketentuan Pasal 346 KUHP dengan tegas melarang tindak aborsi namun, sebagaimana yang diatur dalam kentuan Pasal 75 ayat (2) UU Kesehatan, terdapat pengecualian yaitu karena adanya indikasi keadaan medis darurat yang ditemui mulai dari awal kehamilan, baik yang membahayakan jiwa Ibu dan/atau janin, serta kehamilan dari korban pemerkosaan yang nantinya dapat menyebabkan trauma psikologis. Dalam Pasal 75 ayat (2) UU Kesehatan terdapat ketentuan tambahan terkait diperbolehkannya melakukan aborsi pada kehamilan akibat perkosaan dengan alasan dapat menyebabkan trauma psikologis berat bagi korban perkosaan.

Di samping persoalan kesehatan, aborsi sesungguhnya berkaitan erat dengan persoalan psikologi. Secara mental, perempuan yang memilih melakukan aborsi apapun alasannya, sedang mengalami kegalauan, rasa tidak percaya diri, kekhawatiran yang berlebihan, keputusasaan, atau bahkan penyesalan dan perasaan bersalah dan berdosa. Komplikasi-komplikasi ini tidak jarang berujung pada kematian perempuan, atau cacat permanen. Belum lagi tekanan atas pilihan aborsi yang secara sosial dianggap sebagai tindak kriminal. Alih-alih mendapat dukungan dan penguatan untuk meringankan beban fisik dan psikis yang menerpanya, perempuan malah dicela dan dicaci atau bahkan dihukum penjara.

Selain itu, aborsi hanya dapat dilakukan: a) Sebelum usia kehamilan mencapai 6 (enam) minggu dihitung sejak hari pertama haid terakhir, kecuali dalam hal kedaruratan medis; b) Oleh tenaga kesehatan yang mempunyai keterampilan serta kewenangan dengan memiliki sertifikat yang ditetapkan oleh menteri;c) Ibu hamil yang bersangkutan harus memberikan persetujuan; d) Suami harus memberikan izin, terkecuali bagi korban pemerkosaan; dan e) Pada sarana dan prasarana kesehatan yang memenuhi syarat sebagaimana ditetapkan oleh Menteri. Sehingga aborsi tetaplah ilegal jika praktik aborsi yang dilakukan bertentangan dan diluar ketentuan dalam peraturan perundang-undangan sebagaimana disebut di atas.

Terdapat batasan-batasan serta indikasi dalam mengidentifikasi penyakit yang diderita si Ibu hamil apakah dapat dikategorikan darurat medis didalam dunia kedokteran atau membuat bahaya keselamatan jiwa dan juga mengancam nyawa dan kesehatan janin dalam kandungan, seperti:

a. Sindroma Nefrotik, merupakan salah satu sindrom klinis dengan karakteristik proteinuria berat dan hipoalbuminemia atau hipoproteinemia sebagai konsekuensinya. Pada sindrom nefrotik dengan kehamilan, faktor hipertensi dan insufisiensi ginjal dapat mempengaruhi keluaran bayi; hipertensi sedang-berat atau insufisiensi ginjal dapat memperburuk prognosis keluaran bayi. ${ }^{13}$

\footnotetext{
${ }^{13}$ Qiang Wei, Li Zhang, dan Xinghui Liu. "Outcome of severe preeclampsia manifested as nephrotic syndrome”, Archives of gynecology and obstetrics, 283(2), 201-204, 2011, hlm. 202.
} 
b. Penyakit jantung yang parah pada Ibu hamil. Kehamilan tersebut sangat berisiko padalbu yang hamil karena dapat mengakibatkan dekompensasi jantung, memperburuk penyakit dan mengakibatkan kematian Ibu; sedangkan pada janin yang dikandungdapat menderita kecacatan (akibat genetik, ataupun karena pengaruh warfarin), mengalami kelahiran prematur atau mati saat dilahirkan, morbiditas neonatal dan kematian didalam kandungan;

c. Trauma psikis berat pada Ibu hamil korban perkosaan. Korban perkosaan akan mengalami rasa syok, panik, takut, dan cemas pada umumnya. Tindak perkosaan pasti memberikan trauma mendalam bagi korbannya. Beberapa hal yang dialami secara psikologis oleh korban pemerkosaan, yaitu depresi, sindrom trauma perkosaan, dan gangguan makan; dan

d. Perdarahan hebat pada Ibu hamil.Perdarahan saat kehamilan masih mempunyai peranan penting sampai sekarang ini di dunia sebagai penyebab utama kematian ibu hamil, disusul penyakit darah tinggi dan infeksi pada saat hamil.

Bila dipandang dari keadaan janin yang dikandung, terdapat lima jenis kelainan pada tubuh janin yang membuatnya tidak mempunyai harapan hidup, yaitu: ${ }^{14}$

a. Ectopia Cordis, berarti jantung yang berada di luar rongga dada. Ectopia cordis dapat merupakan kelainan tunggal atau "isolated" yang artinya tidak diserta dengan kelainan lain; atau dapat juga disertai dengan kelaian bawaan lain dan disebut sebagai pentalogi cantrell $;{ }^{15}$

b. Anenchepalusatau anensefali adalah kondisi lahir dengan kecacatan serius dimana bayi yang lahir tidak memiliki sebagian otak serta tengkoraknya;

c. Rachischisis atau yang dikenal juga dengan spina bifida atau myelodisplasia adalah salah satu jenis yang paling sering terjadi dari defek tuba neural (neural tube defect), bersifat non letal, dan non kromosomal. Kondisi ini ditandai dengan penutupan tuba neural yang tidak sempurna pada bagian kaudal lubang neural (neuropore) pada minggu keempat perkembangan janin; ${ }^{16}$

d. Atresia Oesophagus dan Fistula Trakheoesofageal, kelainan esofagus yang bersifat kongenital pada trakeoesofageal fistula (TEF) ditandai dengan adanya fistula atau saluran diantara trakea dan esophagus. Angka kejadian TEF kongenital adalah $1: 2.400-4.500$ kelahiran hidup. ${ }^{17}$ Angka kematian rata-rata

\footnotetext{
${ }^{14}$ Suryono Ekotama, Harum Pudjiarto RS, dan G. Widiartana. Abortus Provocatus Bagi Korban Perkosaan Perspektif Viktimologi, Kriminologi, dan Hukum Pidana. Yogyakarta :Universitas Atma Jaya Yogyakarta, 2001, hlm. 42-43.

15 Amir Hossein Jafarian, et al. "Pentalogy of Cantrell: a case report." Journal of Research in Medical Sciences: The Official Journal of Isfahan University of Medical Sciences, 16(1), 105-109, 2011, hlm. 103.

${ }^{16}$ Waldo Sepulveda, et al. "Prenatal diagnosis of spina bifida: from intracranial translucency to intrauterine surgery", Child's Nervous System, 33(7), 1083-1099, 2017, hlm. 1085.

${ }^{17}$ Edvard Skripochnik, Robert Ashton, dan SiyamekNeragi-Miandoab. "Esophagobronchial fistula following corrosive injury of esophagus: 2 cases with different etiology but similar presentation", The Open Cardiovascular and Thoracic Surgery Journal, 6(1), 16-18, 2013, p. 18.
} 
penderita malformasi esofagus tanpa penyakit jantung kongenital mayor dengan berat badan lahir (BBL) diatas 1.500 gram adalah sebesar 33 persen. Sedangkan angka kematian pada penderita yang disertai penyakit jantung kongenital dengan berat badan lahir dibawah 1.500 gram adalah 100 persen. ${ }^{18}$

Contoh kasus yang cukup menarik adalah putusan Pengadilan Negeri Muara Bulian yang menjatuhkan vonis hukuman 6 bulan penjara dan 3 bulan pelatihan kerja kepada WA, seorang remaja 15 tahun karena melakukan pengguguran kandungan hasil perkosaan yang dilakukan oleh abang kandung sendiri (Putusan Nomor 5/PID. SUSANAK/2018/PN.MBN). Tetapi kemudian WA diputuskan bebas dari segala tuntutan hukum oleh Majelis Hakim Tingkat Banding pada Pengadilan Tinggi Jambi (Nomor Register Perkara: 6/Pid.Sus-Anak/2018/PTJMB).Penegakan hukum dan peradilan di Indonesia dapat menjadikan contoh kasus ini menjadi putusan penting atau sebagai landmark decision. Seringkali perempuan sebagai korban dipandang tidak seimbang utamanya bagi kasus seperti abortus provokatus. Hukum harus bisa menelaah kondisi pelaku tindak pidana, sehingga rasa keadilan bisa terjamin diwujudkan apalagi terdapat unsur keterpaksaan pada korban yang dianggap melakukan tindak pidana. Dalam kondisi korban perkosaan dan dengan alasan indikasi medis sesuai ketentuan UU Kesehatan, maka perlu dipertimbangkan lagi bahwa aborsi merupakan perbuatan yang tidak dapat dimintai pertanggungjawaban pidana nya. ${ }^{19}$

Kenyataan tersebut sejalan dengan Teori Hukum Progresif, yang menegaskan bahwa hukum merupakan sebuah institusi dengan tujuan untuk mengantar manusia mencapai suatu kehidupan yang sejahtera dan adil serta mewujudkan kebahagiaan. ${ }^{20}$ Menjadi dasar asumsi progresifisme hukum adalah pertama hukum diciptakan bukan untuk dirinya sendiri tetapi diciptakan bagi manusia, kedua hukum tidak bersifat final, melainkan selalu berstatus law in the making, ketiga hukum adalah institusi yang bermoral kemanusiaan. ${ }^{21}$

Hukum yang dijalankan dalam penegakan Hukum Progresif menurut Satjipto Rahardjo bukan sekedar hanya kata hitam dan putih dari peraturan (according to the letter), melainkan menurut makna lebih dalam (to very meaning)dan semangat dari hukum atau undang-undang. Penegakan hukum dilakukan memakai kecerdasan spiritual juga, tidak hanya kecerdasan intelektual. Intinya adalah penegakan hukum yang dilakukan harus disertai rasa berani dalam mencari solusi lain ketimbang jalan yang kerap

\footnotetext{
${ }^{18}$ Mihaela Ciornei, et al. "Prognostic factors in the early postoperative outcome of esophageal atresia. the experience of a tertiary center over a 5 years period", Romanian Journal of Pediatrics, 64(3), 71-75, 2015, hlm. 73.

${ }^{19}$ Paulinus Soge. "Legalisasi Aborsi di Indonesia Perspektif Perbandingan Hukum Pidana: Antara Common Law System dan Civil Law System", JurnalHukum IUS QUIA IUSTUM, 16(4), 497-514, 2009, hlm. 499.

${ }^{20}$ Satjipto Rahardjo. Hukum Progresif: Sebuah Sintesa Hukum Indonesia. Yogyakarta: Genta Publishing, 2009, hlm. 2.

${ }^{21}$ Satjipto Rahardjo. Ilmu Hukum; Pencarian, Pembebasan dan Pencerahan. Surakarta: Muhammadiyah Press University, 2004, hlm. 20.
} 
dilakukan dan disertai dedikasi penuh, empati, determinasi, serta komitmen terhadap penderitaan bangsa. ${ }^{22}$

\section{Jangka Waktu Aborsi yang Dapat Diterima Oleh Aspek Kesehatan Perspektif UU Kesehatan}

Pasal 76 ayat (1) UU Kesehatan, disebutkan bahwa hanya dapat melakukan aborsi sebelum kehamilan berumur 6 minggu dihitung sejak hari pertama haid terakhir, terkecuali keadaan darurat medis. Pada Pasal 75 ayat (2) disampaikan bahwa yang dikecualikan pada pelarangan aborsi adalah atas dasar keadaan darurat medis dan hamil karena tindak perkosaan dimana dapat menimbulkan trauma psikis berat bagi korban. Berarti dengan kata lain, aturan dalam Pasal 76 ayat (1) tentang batasan waktu untuk melakukan aborsi yaitu maksimal 6 (enam) minggu terhitung sejak hari pertama haid terakhir, dikhususkan kepada wanita korban perkosaan. Perlu diingat bahwa waktu 6 (enam) minggu tersebut bukanlah dihitung mulai kejadian saat wanita tersebut diperkosa, melainkan merupakan usia kehamilan yang dihitung sejak hari pertama pada terakhir haid.

Ada beberapa penyebab yang mungkin dapat membuat seorang korban perkosaan tidak mempunyai cukup waktu sebelum usia kehamilan 6 minggu untuk melakukan aborsi, yaitu:

a. Beban mental dan psikologis yang sangat berat yang dialami korban perkosaan sehingga dia tidak mampu berpikir jernih untuk melakukan hal hal yang seharusnya dia kerjakan, seperti melaporkan bahwa dia diperkosa terhadap keluarga ataupun pihak yang berwenang. Hampir seluruh korban memilih diam dan tidak menceritakan hal yang dialaminya pada banyak kasus perkosaan. Banyak sekali dijumpai alasan yang membuat mereka enggan untuk menceritakannya, mulai dari merasa takut apa yang diceritakannya tidak akan dipercaya oleh orang lain, kurang percaya terhadap pendengar, merasa malu, bahkan karena takut akan adanya pembalasan. Akhirnya sering sekali korban harus menanggung sendiri beban fisik dan psikologisnya;

b. Korban perkosaan tidak dapat menentukan dirinya hamil atau tidak sampai batas waktu kehamilan 6 minggu terhitung mulai hari pertama haid terakhir. Tidak dijumpai batasan pasti kapan seseorang dimulai dapat dideteksi kehamilannya dalam dunia kedokteran; ${ }^{23}$

c. Tingkat pendidikan yang rendah juga turut memperparah seseorang untuk tidak mengerti apa yang harus dia kerjakan apabila tindak pidana perkosaan dialaminya. Minimnya pengetahuan tentang aturan hukum yang berlaku di Indonesia menjadi momok bagi seorang korban perkosaan untuk mendapatkan

\footnotetext{
${ }^{22}$ Satjipt oRahardjo. Penegakan Hukum Suatu Tinjauan Sosiologis. Yogyakarta: Genta Publishing, 2009, hlm. xiii.

${ }^{23}$ Munawaroh. "Aborsi Akibat Pemerkosaan dan Kedaruratan Medis Menurut Hukum Islam", Mizan: Journal of Islamic Law, 3(2), 295-350, 2018, hlm. 299.
} 
keadilan dan semakin sulit untuk menata langkah terbaik demi menyongsong kehidupan panjang yang akan dilaluinya kelak.

Aborsi untuk korban perkosaan pada prinsipnya sudah dilegalkan di Indonesia. Namun pada umumnya para korban kekerasan seksual mengetahui kehamilannya ratarata di atas 40 hari sehingga membuat hal ini sedikit sulit untuk dilaksanakan oleh korban pemerkosaan. ${ }^{24}$ Jika dilihat dari sudut pandang daluwarsa pelaporan terkait pidana pemerkosaan merujuk pasal $78 \mathrm{KUHP}$, maka upaya penuntutan pidananya menjadi hapus atau tidak dapat dilakukan penuntutan sesudah 12 (dua belas) tahun. Artinya seorang korban perkosaan masih bisa melaporkan tindak pidana yang dialaminya sampai 12 tahun sesudahnya. Namun, sesuai UU Kesehatan, aborsi hanya dapat dilakukan bagi korban perkosaan apabila usia kehamilan maksimal 6 (enam) minggu terhitung mulai hari pertama haid terakhir.Apabila aborsi tidak dapat dilakukan oleh seorang wanita korban perkosaan sebelum usia kandungan 6 (enam) minggu, maka dia akan terpaksa untuk tetap melanjutkan kehamilannya sampai kelahiran nanti. Tetapi hal tersebut tentu akan menimbulkan banyak efek negatif, diantaranya: 1) Gangguan psikologis dan kesehatan mental yang terganggu; 2) Dikucilkan masyarakat dan kesehatan sosial terganggu;dan 3) Kesehatan ekonomi yang terganggu. ${ }^{25}$

Sebagai perbandingan, jika merujuk terhadap aturan yang sudah legal dan dijalankan di Jerman, aborsi hanya dapat dilakukan dengan batas usia kehamilan sebelum mencapai 3 bulan jika kehamilan tersebut mengancam nyawa sang Ibu dan pada kasus kehamilan akibat korban perkosaan. Dengan mempertimbangkan uraian sebelumnya tentang keadaan psikologis dan mental korban perkosaan, tentu hal itu dapat menjadi acuan pada kasus wanita yang hamil akibat perkosaan di Indonesia, dimana pengaturan tentang maksimal umur kehamilan untuk boleh melakukan aborsi ditambahkan menjadi 12 minggu ( 3 bulan). ${ }^{26}$

Masih terjerembabnya kepada paradigma tunggal positivisme merupakan satu dari beberapa alasan mengapa terjadi perlambatan pada dunia hukum. Pada kenyataannya hal tersebut sudah lagi tidak berfungsi sebagai kontrol dan analisis yang sejalan dengan tabel hidup karakteristik manusia baik pada proses maupun pada peristiwa hukum yang senyatanya pada konteks multi kepentingan dan dinamis. ${ }^{27}$ Pada akhirnya hukum dimaknai hanya sebatas undang-undang dalam artian hanya dipahami dalam artian sangat sempit. Sebaliknya nilai yang adadiluar peraturan perundangan tidak bermakna sebagai hukum juga. Terjadi secara bergantian perubahan politikdidalam sejarah Negara Republik Indonesia, antara konfigurasi politik otoriter dengan yang demokratis. Produk hukum juga memiliki karakter yang ikut berubah seiringan perubahan konfigurasi politik tersebut. Ketika politik memiliki konfigurasi dengan tampilan otoriter, maka akan

24 Dwight Nusawakan. "Kebijakan Kriminal Terhadap Tindakan Aborsi", Pasapua Health Journal, 1(1), 18-26, 2019, hlm. 23.

${ }^{25}$ Aji Mulyana. "Perlindungan HukumTerhadap Perempuan dan Anak Akibat Tindak Pidana Abortus Provokatus Criminalis", Jurnal Wawasan Yuridika, 1(2), 139-154, 2017, hlm. 145.

${ }^{26}$ Riza Yuniar Sari. "Aborsi Korban Perkosaan Perspektif Hukum Islam dan Hak Asasi Manusia”, Al-Hukama', 3(1), 34-82, 2013, hlm. 41.

${ }^{27}$ Sabian Usman. Dasar-Dasar Sosiologi Hukum. Yogyakarta. Pustaka Belajar, 2009, hlm. 219. 
berkarakter ortodoks lah hukum yang dilahirkan. Sedangkan ketika politik memiliki konfigurasi yang menjunjung nilai-nilai demokrasi, maka akan berkarakter responsif lah produk hukum yang dihasilkan. ${ }^{28}$

Terdapat perubahan sistem hukum yang ada di Indonesia akibat terciptanya pola kehidupan bernegara yang lebih demokrasi sebagai bagian akibat dari bergulirnya reformasi yang terjadi di Indonesia. Keadilan dalam kehidupan bermasyarakat lebih dikedepankan dibanding keadilan yang dikebiri oleh Penguasa, dimana sistem hukum berubah menjadi model terbuka yang sebelumnya dari model tertutup. Hal ini sesuai dengan karakteristik Teori Hukum Progresif, dimana pada metode penemuan hukum ini memiliki keberanian dalam membuat suatu terobosan (rule breaking) seiring terjadinya dinamika dalam kehidupan bermasyarakat, namun tentu saja memihak dan peka terhadap nasib dan keadaan bangsa dan negaranya dengan tetap berpedoman pada hukum, keadilan dan kebenaran. ${ }^{29}$

Dalam mengimbangi berkembangnya kebutuhan manusia terhadap perlindungan dan jaminan hukum, maka hukum dituntut untuk selalu 'bergerak' oleh konsep hukum progresif. Dalam pengertian hukum sebagai suatu proyek dan proses maka hukum berarti memiliki status "law in the making". Hukum diharuskan membuka hati dan diri untuk menemukan keadilan, sehingga tidak terbelenggu pada pemikiran "apa yang dikatakan undang-undang”. Satjipto Rahardjo menekankan bahwa mobilisasi hukum sangat penting dilakukan dengan bertumpu pada sumber daya manusia dalam hukum untuk jangan selalu terkekang dengan aturan hukum, melainkan berani melakukan interpretasi secara progresif. $^{30}$ Dalam melayani manusia dan kebutuhannya pada sebuah sistem sosial bermasyarakat, maka hukum memainkan peran tersendiri. Sehingga dapat disimpulkan bahwa hukum merupakan salah satu bagian dari ilmu sosial yang memiliki orientasi terhadap kepentingan dan kebutuhan kehidupan bermasyarakat.

\section{Penutup}

UU Kesehatan yang terkait abortus provokatus merupakan aturan yang realistis berdasarkan aspek kesehatan. KUHP melarang pelaksanaan aborsi tanpa diberi pengecualian. Sebaliknya UU Kesehatan justru memperbolehkan dilakukannya aborsi provokatus medicinalis dan aborsi provokatus therapeuticus. Didalam dunia kesehatan dijumpai kedaruratan medis pada ibu hamil dan janin kandungannya yang membuat si ibu sebaiknya menggugurkan kandungannya. Kedaruratan pada Ibu hamil tersebut antara lain: sindroma nefrotik, penyakit jantung yang parah, perdarahan hebat, dan juga trauma psikis yang berat bagi korban perkosaan. Sementara itu kelainan janin yang membuat ketiadaan harapan hidup saat dilahirkan, antara lain: Ectopia cordis, Anenchepalus,

\footnotetext{
${ }^{28}$ Mahfud MD.Politik Hukum di Indonesia. Jakarta: Rajawali Pers, 2009, hlm. 373.

${ }^{29}$ Ahmad Rifai. Penemuan Hukum oleh Hakim dalam Perspektif Hukum Progresif. Jakarta: Sinar Grafika, 2010, hlm. 93.

${ }^{30}$ Melani, Hari Sutra Disemadi, NyomanSerikat Putra Jaya. "Kebijakan Hukum Pidana Dibidang Transaksi Elektronik Sebagai Tindak Pidana Non-Konvensional", Pandecta: Jurnal Penelitian Ilmu Hukum (Research Law Journal), 15(1), 111-120, 2020, hlm. 117.
} 
Rachischisis, serta Atresia Oesophagus dan Fistula Trakheoesofageal. Dengan demikian dapat disimpulkan bahwa UU Kesehatan sebagai Lex Specialis diberlakukan terhadap korban perkosaan apabila terdapat alasan indikasi medis sesuai ketentuan UU Kesehatan. Dengan demikian, aborsi dapat diberlakukan terhadap korban permerkosaan dan yang bersangkutan (korban pemerkosaan) tidak dapat dimintai pertanggungjawaban pidana sebagaimana yang diatur oleh KUHP.

Menurut UU Kesehatan, aborsi hanya dapat dilakukan oleh korban perkosaan apabila kehamilan maksimal berumur 6 (enam) minggu atau 40 (empat puluh) hari dihitung sejak hari pertama haid terakhir, dan tentu saja limit waktu tersebut jelas tidak cukup. Perlu diingat bahwa waktu 6 (enam) minggu tersebut bukanlah dihitung mulai kejadian saat wanita tersebut diperkosa, melainkan merupakan usia kehamilan yang dihitung sejak hari pertama haid terakhir. Maka, sebaiknya batas waktu yang aman untuk kesehatan seorang perempuan secara medis untuk dilakukan tindakan aborsi bisa dijadikan sebagai pedoman dan acuan, dimana usia kehamilan untuk boleh dilakukan aborsi ditingkatkan menjadi 12 minggu atau 3 bulan terhitung sejak hari pertama haid terakhir. Saran ini sesuai pendekatan Teori Hukum Progresif yang menghendaki adanya suatu terobosan (rule breaking) seiring terjadinya dinamika dalam kehidupan bermasyarakat, namun tetap berpedoman pada hukum, keadilan dan kebenaran.

\section{Daftar Pustaka}

\section{A. Buku}

Abdul Aziz Dahlan. Ensiklopedi Hukum Islam. Jakarta: PT. Ikhtisar Baru Van Hoev, 1996.

Achadiat Charisdiono, Dinamika Etika dan Hukum Kedokteran, Jakarta: Buku Kedokteran, 2007.

Ahmad Rifai. Penemuan Hukum oleh Hakim dalam Perspektif Hukum Progresif. Jakarta: Sinar Grafika, 2010.

Kusmaryanto. Kontroversi Aborsi, Jakarta : Gramedia Widiasarana Indonesia, 2002.

Mahfud MD. Politik Hukum di Indonesia. Jakarta: Rajawali Pers, 2009.

Maria Ulfah Ansor, Wan Nedra, dan Sururin. Aborsi Dalam Perspektif Figh Kontemporer. Jakarta: Balai Penerbit Fakultas Kedokteran Universitas Indonesia, 2002.

Musa Perdanakusuma. Bab Bab Tentang Kedokteran Forensik. Jakarta: Ghalia Indonesia, 1984.

Rukmini Mien. Laporan Akhir Penelitian Tentang Aspek Hukum Pelaksanaan Aborsi Akibat Perkosaan, Jakarta: Badan Pembinaan Hukum Nasional Departemen Kehakiman dan HAM, 2002.

Sabian Usman. Dasar-Dasar Sosiologi Hukum. Yogyakarta. Pustaka Belajar, 2009. 
Satjipto Rahardjo. Hukum Progresif: Sebuah Sintesa Hukum Indonesia. Yogyakarta: Genta Publishing, 2009.

Satjipto Rahardjo. Ilmu Hukum; Pencarian, Pembebasan dan Pencerahan. Surakarta: Muhammadiyah Press University, 2004.

Satjipto Rahardjo. Penegakan Hukum Suatu Tinjauan Sosiologis. Yogyakarta: Genta Publishing, 2009.

Suryono Ekotama, Harum Pudjiarto RS, dan G. Widiartana. Abortus Provocatus Bagi Korban Perkosaan Perspektif Viktimologi, Kriminologi, dan Hukum Pidana. Yogyakarta : Universitas Atma Jaya Yogyakarta, 2001.

Suryono Ekototama. Abortus Prookatus bagi Korban Perkosaan Perspektif Viktimologi, Kriminologi dan Hukum Pidana. Yogyakarta: Universitas Admajaya, 2001.

\section{B. Jurnal}

Aji Mulyana. "Perlindungan Hukum Terhadap Perempuan dan Anak Akibat Tindak Pidana Abortus Provokatus Criminalis", Jurnal Wawasan Yuridika, 1(2), 139-154, 2017.

Amir Hossein Jafarian, et al. "Pentalogy of Cantrell: a case report." Journal of Research in Medical Sciences: The Official Journal of Isfahan University of Medical Sciences, 16(1), 105-109, 2011.

Dwight Nusawakan. "Kebijakan Kriminal Terhadap Tindakan Aborsi”, Pasapua Health Journal, 1(1), 18-26, 2019.

Edvard Skripochnik, Robert Ashton, dan Siyamek Neragi-Miandoab. "Esophagobronchial fistula following corrosive injury of esophagus: 2 cases with different etiology but similar presentation", The Open Cardiovascular and Thoracic Surgery Journal, 6(1), 16-18, 2013.

Linda Fidawaty. "Aborsi dalam Perspektif Hak Asasi Manusia dan Hukum Islam (Analisis terhadap Peraturan Pemerintah No. 61 tahun 2014 tentang Kesehatan Reproduksi)", Al-'Adalah, 14(1), 107-130, 2017.

Melani, Hari Sutra Disemadi, Nyoman Serikat Putra Jaya. "Kebijakan Hukum Pidana Dibidang Transaksi Elektronik Sebagai Tindak Pidana Non-Konvensional", Pandecta: Jurnal Penelitian Ilmu Hukum (Research Law Journal), 15(1), 111-120, 2020.

Mihaela Ciornei, et al. "Prognostic factors in the early postoperative outcome of esophageal atresia. the experience of a tertiary center over a 5 years period", Romanian Journal of Pediatrics, 64(3), 71-75, 2015.

Mufidatul Ma'sumah. "Penjatuhan Pidana Terhadap Anak Korban Perkosaan Inses Yang Melakukan Aborsi”, Jurnal Yudisial, 12(2), 255-268, 2019.

Munawaroh. "Aborsi Akibat Pemerkosaan dan Kedaruratan Medis Menurut Hukum Islam”, Mizan: Journal of Islamic Law, 3(2), 295-350, 2018.

Paulinus Soge. "Legalisasi Aborsi di Indonesia Perspektif Perbandingan Hukum Pidana: Antara Common Law System dan Civil Law System", Jurnal Hukum IUS QUIA IUSTUM, 16(4), 497-514, 2009. 
Qiang Wei, Li Zhang, dan Xinghui Liu. "Outcome of severe preeclampsia manifested as nephrotic syndrome", Archives of gynecology and obstetrics, 283(2), 201-204, 2011.

Riza Yuniar Sari. “Aborsi Korban Perkosaan Perspektif Hukum Islam dan Hak Asasi Manusia”, Al-Hukama', 3(1), 34-82, 2013.

Sahuri Lasmadi, Ahmad Rofiq, Hari Sutra Disemadi, Sholahuddin Al-Fatih. "Islamic Criminal Law Review on the Duality of Principles of Legality in the Draft of Indonesia Criminal Law Code", International Journal of Innovation, Creativity and Change, 14 (2), 942-958, 2020.

Triana Dewi Seroja, Winda Fitri. "Implementasi dan Implikasi Asas Kekhususan Sistematis pada Tindak Pidana Telekomunikasi", Journal of Law and Policy Transformation, 4(2), 104-122, 2019.

Waldo Sepulveda, et al. "Prenatal diagnosis of spina bifida: from intracranial translucency to intrauterine surgery", Child's Nervous System, 33(7), 1083-1099, 2017. 